\title{
SISTEM PAKAR PENDIAKNOSAAN HAMA DAN PENYAKIT PADA TANAMAN TEH MENGGUNAKAN METODE CASE-BASED REASONING BERBASIS ANDROID
}

\author{
Agus Suryadi $^{* 1)}$, Dasman Johan ${ }^{* 2)}$, Eka Lia Febrianti ${ }^{* 3)}$ \\ ${ }^{1}$ Teknik Informatika, Universitas Ibnu Sina \\ ${ }^{2}$ Teknik Industri, Universitas Ibnu Sina \\ ${ }^{3}$ Teknik Perangkat Lunak, Universitas Universal \\ e-mail: agussuryadi@stt-ibnusina.ac.id, dasman.johan@stt-ibnusina.ac.id, \\ ekalia88@gmail.com
}

\begin{abstract}
Abstrak
Perancangan aplikasi android Case-based rasoning (CBR) merupakan metode yang di gunakan untuk membangun sebuah sistem berbasis pengetahuan.Sumber pengetahuan sistem di peroleh dengan mengumpulkan penanganan kasus-kasus oleh seorang ahli atau pakar. Dalam penelitian ini peneliti membuat atau menganalisa penyakit Tanaman Teh melalui gejala-gejala yang dialami oleh Tanaman tersebut sehingga dapat membantu seseorang atau petani dalam mendiagnosa jenis penyakit dan hama tanaman teh berdasarkan gejalagejalanya.Keuntungan dengan penerapan metode ini adalah petani tidak perlu menanyakan gejala dan penyakit pada seorang pakar.Aplikasi ini diharapkan dapat memudahkan petani untuk mengenali jenis hama dan penyakit pada tanaman teh dan juga aplikasi ini terdapat perhitungan dengan jelas mengenai hama dan penyakit tanaman teh.
\end{abstract}

Kata kunci - Case-Based Reasoning (CBR), Sistem Pakar, Android Studio

\section{Abstract}

The design of a Case-based rasoning android application (CBR) is a method used to build a knowledge-based system. The source of system knowledge is obtained by collecting case handling by an expert or expert. In this study researchers made or analyzed the disease of Tea Plants through the symptoms experienced by these Plants so that it can help a person or farmer in diagnosing types of diseases and pests of tea plants based on their symptoms. The advantage of applying this method is that farmers do not need to ask for symptoms and disease in an expert. This application is expected to make it easier for farmers to recognize the types of pests and diseases in tea plants and also this application there is a clear calculation of pests and diseases of tea plants.

Keywords - Case-Based Reasoning (CBR), Expert System, Android Studio

JURSIMA

Jurnal Sistem Informasi dan Manajemen https://ejournal.stmikgici.ac.id/

STMIK GICI 


\section{PENDAHULUAN}

Secara umum, sistem pakar adalah sistem yang berusaha mengadopsi pengetahuan manusia ke komputer yang dirancang untuk memodelkan kemampuan menyelesaikan masalah seperti layaknya seorang pakar. Dengan sistem pakar ini, orang awam pun dapat menyelesaikan masalahnya atau hanya mencari informasi berkualitas yang sebenarnya hanya dapat diperoleh dengan bantuan para ahli di bidangnya. Sistem pakar ini juga dapat membantu aktivitas para pakar sebagai asisten yang berpengalaman dan mempunyai pengetahuan yang dibutuhkan. (Febrianti \& Christi, 2017).

Android adalah sebuah sistem operasi pada smartphone yang bersifat terbuka dan berbasis pada sistem operasi Linux. Android bisa digunakan oleh setiap orang yang ingin menggunakannya pada perangkat mereka. Android menyediakan platform terbuka bagi para pengembang untuk menciptakan aplikasi mereka sendiri yang akan digunakan untuk bermacam peranti bergerak. Kelebihan dari android adalah sifatnya yang opensource dan mudah dikembangkan. (Suryadi, Nasution, \& Febrianti, 2018).

Pada penelitian ini, akan diterapkan suatu metode untuk membantu menentukan penyakit tanaman Teh berdasarkan gejalanya yaitu Metode CaseBased Reasoning. Tujuan pembuatan aplikasi ini yaitu mengimplementasikan Metode Case-Based Reasoning dalam menganalisis penyakit Tanaman Teh melalui gejala-gejala yang dialami oleh Tanaman tersebut sehingga dapat membantu seseorang dalam mendiagnosa jenis penyakit berdasarkan gejalagejalanya.

Case Based Reasoning adalah metode untuk menyelesaikan masalah dengan mengingat kejadiankejadian yang sama/sejenis (similar) yang pernah terjadi di masa lalu kemudian menggunakan pengetahuan/informasi tersebut untuk menyelesaikan masalah yang baru, atau dengan kata lain menyelesaikan masalah dengan menghadapi solusisolusi yang pernah digunakan di masa lalu (2013, Suriyanti).

\section{METODE PENELITIAN}

Makna penelitian secara sederhana adalah bagaimana mengetahui sesuatu yang dilakukan melalui cara tertentu dengan prosedur yang sistematis. Maka peneliti membentuk kerangka penelitian sebagai berikut :

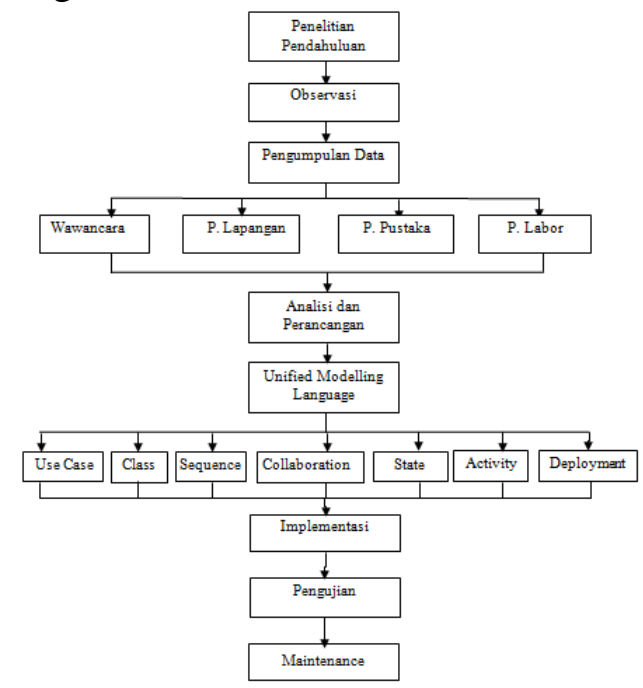

Gambar 1. Kerangka Penelitian

\section{Penelitian Pendahuluan}

Penelitian pendahuluan ini merupakan langkah pertama dalam 
melakukan suatu penelitian. Penelitian dilaksanakan di Dinas Pertanian Kota Solok. Bertujuan untuk membantu petani dalam menentukan hama dan penyakit yang menyerang. Penelitian pendahuluan ini dilakukan dengan cara mendatangi langsung pakar yang memahami tentang hama dan penyakit tanaman teh.

\section{Pengumpulan Data}

Dalam melakukan proses pengumpulan data, peneliti melakukan wawancara secara langsung dengan Bapak Agus Silagan, SP yang menjabat sebagai sebagai Kepala UPT Perlindungan Tanaman di Dinas Pertanian Kota Solok. Peneliti mendapatkan beberapa informasi penting yang berhubungan dengan penelitian yang sedang dilakukan.

\section{Analisa}

Untuk melakukan penelitian, peneliti melakukan analisa terhadap datadata yang telah dikumpulkan serta menganalisa sistem yang akan dijalankan sebagai solusi dari perumusan masalah yang didapat dengan cara analisa data, analisa proses dan analisa sitem.

\section{Perancangan}

Dalam tahap perancangan ini, Peneliti menggunakan metode UML dalam melakukan perancangan model pada sistem pengambilan keputusan ini. Adapun UML (Unified Modelling language) yang akan digunakan adalah sebagai berikut:

\section{a. Use Case Diagram}

Use case diagram ini menunjukkan fungsionalitas yang di harapkan dalam system aplikasi sistem pakar ini. Dimana use case diagram ini terdiri atas diagram untuk use case admin dan user.

\section{b. Class Diagram}

Class Diagram dari suatu sistem akan menggambarkan juga bagaimana struktur database yang di butuhkan untuk membangun sistem tersebut. Pada sistem pakar ini akan terdapat class admin, user, hama, penyakit, gejala, hasil dan solusi.

c. Sequence Diagram

Sequence Diagram menggambarkan kelakuan use case dengan mendeskripsikan waktu hidup objek dan message yang di kirim dan di terima antar objek

\section{Collaboration Diagram}

Collaboration

Diagram menggambarkan bagaimana peran-peran pada setiap objek sehingga lebih jelas dan terorganisasi. Collaboration Diagram menunjukkan messages objek yang dikirimkan satu sama lain.

\section{State Chart Diagram}

State Chart Diagram akan menggambarkan cara memodelkan berbagai state (keadaan) keberadaan objek, digunakan untuk memodelkan lebih dinamis perilaku dari sistem.

\section{Activity Diagram}

Diagram aktifitas atau Activity diagram menggambarkan workflow (aliran kerja) atau aktivitas dari sebuah sistem atau proses kerja atau menu yang ada pada perangkat lunak. Pada sistem ini akan di jelaskan aktifitas yang dapat di lakukan oleh aktor yang ada pada sistem, yaitu admin dan user.

\section{Deployment Diagram}

Pada Deployment Diagram menggambarkan bagaimana komponen di-delay dalam sistem dan di-node (pada mesin, server, atau perangkat keras) dimana akan ditempatkan. Deployment diagram mendefinisikan hubungan antar node dan requitmen.

https://ejournal.stmikgici.ac.id/ STMIK GICI 


\section{Implementasi}

Implementasi sistem merupakan tahap memetakan sistem sehingga siap untuk di operasikan. Implementasi bertujuan untuk mengkonfirmasi modulmodul perancangan, sehingga pengguna dapat memberi masukan kepada pengembangan sistem. Pada tahap ini perancangan sistem di lakukan dengan menggunakan bahasa pemrograman JAVA dan SQLite.

\section{Pengujian}

Pengujian ini di lakukan dengan membandingkan keluaran atau Output dari sistem dengan hasil perhitungan manual terhadap sejumlah rumus yang ada dalam metode CBR. Pengujian aplikasi di lakukan dengan melihat kesesuaian antara output yang di berikan sebagai hasil analisis dari aplikasi dengan kondisi yang sebenarnya. Dan setelah pengkodean selesai maka akan dilakukan proses pengujian terhadap aplikasi yang dihasilkan untuk mengetahui apakah aplikasi yang dirancang sudah berjalan dengan benar dan sesuai.

\section{HASIL DAN PEMBAHASAN}

\section{Hasil}

\section{Tampilan Menu Utama}

Merupakan tampilan awal menu utama yang menampilkan menu utama ini terdapat beberapa menu yang dapat diakses oleh user. Tampilan Menu utama dapat dilihat pada gambar 2. berikut:

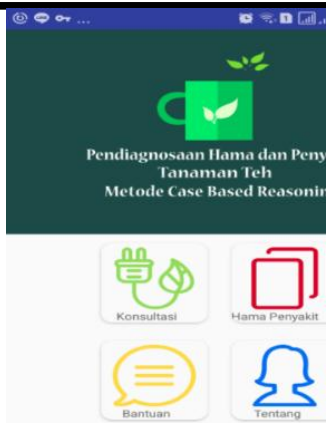

\section{Gambar 2. Tampilan Menu Utama}

2. Tampilan Menu Konsultasi

Halaman konsultasi berisi petunjuk konsultasi dan satu tombol untuk mulai konsultasi. Tampilan konsultasi dapat dilihat pada gambar 3 berikut:

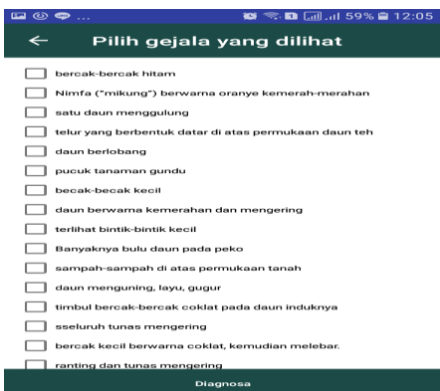

Gambar 3. Tampilan Menu Konsultasi

3. Tampilan Pemilihan Gejala

Tampilan Pemilihan Gejala berisi gejala-gejala hama dan penyakit yang di alami oleh tanaman teh dan dipilih untuk melakukan pendiagnosaan. Tampilan pemilihan gejala dapat dilihat pada gambar 4 berikut: 


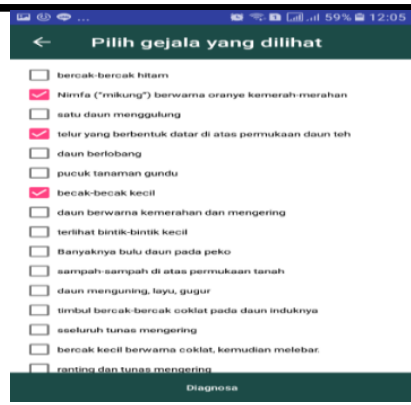

Gambar 4. Tampilan Pemilihan Gejala

4. Tampilan Proses Kepik Penghisap Daun Teh

Tampilan Proses Kepik Penghisap Daun Teh berisi detail informasi hama atau penyakit, gejala kasus, perihitungan kasus dan solusi. Tampilan proses hama thrips dapat dilihat pada gambar 5 berikut:

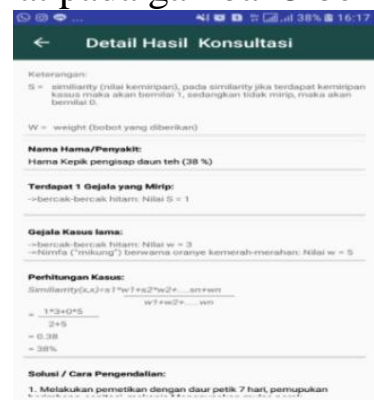

\section{Gambar 5. Kepik Penghisap Daun}

Teh

5. Tampilan Proses Hama Ulat Jengkal Tampilan proses hama Ulat Jengkal dapat dilihat pada gambar berikut:

$$
\leftarrow \text { Detail Hasil Konsultasi }
$$

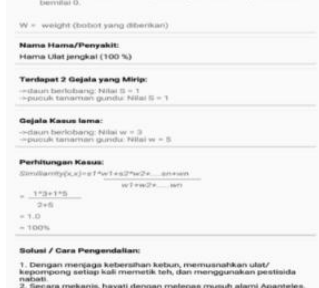

Gambar 6. Proses Hama Ulat Jengkal

6. Tampilan Proses Hama Tungau Jingga
Tampilan proses hama tungau Jingga dilihat pada gambar 7 berikut:

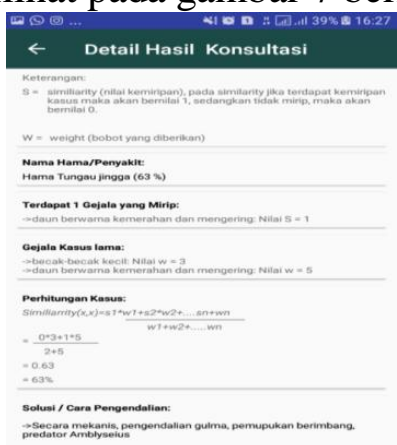

\section{Gambar 7. Proses Hama Tungau Jingga}

7. Tampilan Menu Hama Penyakit Tampilan Menu Hama Penyakit dapat dilihat pada gambar 8 berikut:

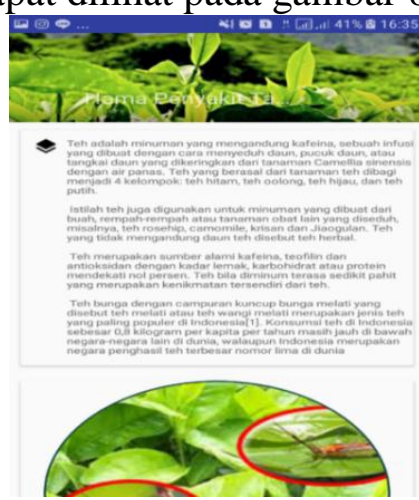

\section{Gambar 8. Menu Hama Penyakit}

8. Tampilan Menu Bantuan

Halaman Bantuan berisi penjenjelasan penggunaan menu aplikasi. Tampilan Menu Bantuan dapat dilihat pada gambar 9 berikut: 
dirasakan oleh tanaman teh pada aplikasi sistem pakar :

Tabel 1. Kasus Baru User (x)

\begin{tabular}{|c|l|c|}
\hline Kode & \multicolumn{1}{|c|}{ Gejala yang dilihat } & Bobot \\
\hline G01 & bercak-bercak hitam & 3 \\
\hline G03 & satu daun mengguang & 3 \\
\hline G11 & $\begin{array}{l}\text { sampah-sampah di } \\
\text { atas permukaan tanah }\end{array}$ & 3 \\
\hline G12 & $\begin{array}{l}\text { daun menguning, } \\
\text { layu, gugur }\end{array}$ & 5 \\
\hline
\end{tabular}

Gambar 9. Menu Bantuan

\section{PEMBAHASAN}

Analisa data bertujuan untuk membatasi subjek dan objek yang akan diteliti agar menjadi sebuah informasi yang lebih sistematis dan mudah dimengerti. Perancangan pada analisa data ini terdiri dari analisa data hama atau penyakit yang disertai dengan data solusi atau cara pengendaliannya, data gejala tersebut dilanjutkan dengan data keterangan tentang bagaimana user seharusnya bersikap, apakah hama atau penyakit pada tanaman teh tersebut dapat dicegah.

Tahapan analisa proses dilakukan dengan menggunakan metode Case-Based Reasoning (CBR) serta menerapkan algoritma Nearest Neighbour Retrieval (K-NN). Dalam metode CBR, terdapat empat tahapan proses didalamnya, yaitu retrive, reuse, revise dan retain. Sistem ini pada umumnya berpedoman pada basis pengetahuan yang dimiliki oleh sistem itu sendiri.

Sebagai contoh, berikut data gejala hama atau penyakit tanaman teh yang

\section{Proses Retrieve}

Proses retrieve merupakan proses pencarian kemiripan kasus baru dengan kasus yang ada pada basis pengetahuan. Pencarian kemiripan tersebut dilakukan dengan cara mencocokkan gejala yang di inputkan oleh pengguna dengan gejala yang ada pada basis pengetahuan. Pada proses retrieve ini akan dilakukan pembobotan dengan menggunakan algoritma Nearest Neighbour Retrieval (K-NN).

Pada awal proses diagnosa pengguna akan menginputkan gejalagejala yang dialaminya secara sekaligus tanpa memerlukan banyak pertanyaan, selanjutnya pengguna akan mendapatkan hasil diagnosa. Sistem akan melakukan pembobotan dengan melakukan pencocokan satu per satu antara gejalagejala yang ada didalam basis pengetahuan.

Adapun tahap pemrosesan kemiripan bobot yang dilakukan sistem akan dihitung dengan rumus berikut:

Similiarity (Problem, Case)

$=\underline{s 1 * w 1+s 2 * w 2+. . s n * w n}$ $w 1+w 2+\ldots w n$

Keterangan : 
S = Similiarity (nilai kemiripan), pada similarity jika terdapat kemiripan kasus akan bernilai 1, sedangkan tidak mirip, maka akan bernilai 0 .

$\mathrm{W}=$ Weight (bobot yang diberikan).

Perhitungan Kasus Hama Kepik pengisap daun teh

\begin{tabular}{|c|c|}
\hline Gejala awal & $\begin{array}{c}\text { Bo } \\
\text { bot }\end{array}$ \\
\hline $\begin{array}{c}\text { bercak-bercak } \\
\text { hitam }\end{array}$ & 3 \\
\hline $\begin{array}{c}\text { Nimfa } \\
\text { ("mikung") } \\
\text { berwarna oranye } \\
\text { kemerah-merahan }\end{array}$ & 5 \\
\hline
\end{tabular}

\begin{tabular}{|c|c|c|}
\hline Kode & $\begin{array}{c}\text { Gejala yang } \\
\text { dirasakan }\end{array}$ & Bobot \\
\hline G01 & $\begin{array}{c}\text { bercak-bercak } \\
\text { hitam }\end{array}$ & 3 \\
\hline G02 & $\begin{array}{c}\text { satu daun } \\
\text { mengguang }\end{array}$ & 3 \\
\hline G11 & $\begin{array}{c}\text { sampah- } \\
\text { sampah di atas } \\
\text { permukaan } \\
\text { tanah }\end{array}$ & 3 \\
\hline G12 & $\begin{array}{c}\text { daun } \\
\text { menguning, } \\
\text { layu, gugur }\end{array}$ & 5 \\
\hline
\end{tabular}

Gambar 10. Skema Kasus Hama

Kepik pengisap daun teh

Similiarity $(x, x)$

$$
=\underline{s l * w 1+s 2 * w 2+. . s n * w n}
$$$$
w 1+w 2+\ldots w n
$$$$
=\frac{1 * 3+0 * 5}{3+5}
$$

$=\underline{3}$

$$
=0.375
$$

$=37.5 \%$

Dari perhitungan kasus diatas terdapat 1 gejala yang dilihat oleh user memiliki kemiripan dengan kasus lama. sehingga dari perhitungan similarity, tingakat Hama Kepik pengisap daun teh yang akan dialami oleh tanaman sebesar $37.5 \%$. Untuk membangun sistem ini, instalasi software pendukung diantaranya Instalasi JDK (Java Development Kit), Instalasi Android Studio.

\section{SIMPULAN}

Dari uraian masalah di atas, serta berdasarkan analisa dari bab-bab yang ada, maka dapat ditarik kesimpulan sebagai berikut:

1. Perancangan sistem pakar dapat mempermudah dalam melakukan pendiagnosaan terhadap hama dan penyakit tanaman teh, dari penelusuran gejala-gejala yang dirasakan dengan hasil diagnosa dari sebuah hama atau penyakit tanaman teh berdasarkan fakta yang terjadi sebelumnya.

2. Sistem pakar dengan metode CBR dapat memberikan suatu solusi atau cara pengengendalian hama atau penyakit tanaman teh sehingga dapat membantu keefektifan waktu dan biaya user dalam menanggulangi hama atau penyakit yang terjadi.

3. Sistem pakar ini penelusurannya menggu nakan metode CBR (Case Based Reasoning) dapat menghasilkan solusi pada tanaman teh atau orang pertanian yang ahli di bidang penyakit dan hama tanaman.

\section{UCAPAN TERIMA KASIH}

Ucapan terimakasih disampaikan kepada semua kalangan yang terlibat dalam kegiatan penelitian ini. Kepada ketua yayasan yang telah bersedia memberikan dana untuk kelancaran kegiatan penelitian ini serta kepada LPPM dan dosen-dosen lainnya yang terlibat sehingga kegiatan penelitian ini berjalan sebagaimana mestinya. 


\section{DAFTAR PUSTAKA}

Aini, Nur, Ramadiani Ramadiani, and Heliza Rahmania Hatta. "Sistem Pakar Pendiagnosa Penyakit Tuberkulosis." Jurnal Informatika Mulawarman (JIM) 12.1 (2017): 5663.

Febrianti, E. L., \& Christi, T. (2017).

Peneraan Forward Chaining Untuk

Mendianogsa Penyakit Malaria Dan

Pencegahanya Berbasis Web.

JURTEKSI, 4(1), 93-100.

Suryadi, A., Nasution, A., \& Febrianti, E. L. (2018). Pengenalan Dan Pelatihan Bahasa Pemograman Android Pada Siswa SMK Negeri 1 Air Joman-

Kisaran. Jurdimas (Jurnal

Pengabdian Kepada Masyarakat)

Royal, 1(2), 1-4.

Juansyah, Andi. "Pembangunan Aplikasi Child Tracker Berbasis AssistedGlobal Positioning System (A-GPS) Dengan Platform Android." (2016).

Mubarok, Akhmad Husain. "Aplikasi Panduan Teknisi Berbasis Android Untuk Mempermudah Penanganan Troubleshooting Pada PT KAI (Persero) Daop 3 Cirebon." JURNAL ICT 13.1 (2016).

Palabiran, Meides, Dedy Cahyadi, and Zainal Arifin. "Sistem Informasi Geografis Kuliner, Seni dan Budaya kota balikpapan berbasis Android." Jurnal Informatika Mulawarman (JIM) 10.1 (2016): 54-57.

Rackman, Muklis Budi, and Ardianto Ardianto. "Sistem Pakar untuk Diagnosis Penyakit pada Tanaman Teh dengan Metode Fuzzy Logic Berbasis Android." (2014). 